\title{
Energy Consumption of Beech Timber Drying in Oscillation Climates
}

\section{Potrošnja energije tijekom oscilacijskog sušenja bukovih piljenica}

\author{
Original scientific paper • Izvorni znanstveni rad \\ Received-prispjelo: 17. 12. 2013. \\ Accepted-prihvaćeno: 13. 10. 2014. \\ UDK: $630 * 847.24 ; 630 * 847.7 ; 674.031 .632 .22$ \\ doi:10.5552/drind.2014.1367
}

\begin{abstract}
The influence of applying the oscillations of air parameters during conventional drying of beech timber on energy consumption is discussed in the paper. A special drying software was created to enable the input of frequency (in hours) and amplitude (in percents) of oscillations. Altogether 12 drying runs were carried out: three conventional ones and nine by using the same schedule but with oscillations of equilibrium moisture content (EMC), temperature and the combination of these two. The combinations of two amplitudes (10\% or $20 \%)$ and two frequencies (3 or 6 hours) were applied in different test runs. The results indicated that all test runs had energy consumptions proportional to drying time, with an important influence of the outside temperature. In runs with oscillations, often climate changes influenced to some extent the total energy consumption, especially in runs with short phases (3 hours) and high amplitudes (20\%). Despite frequent climate changes, it can be expected that the usage of oscillations would lead to the same or even lower energy consumption than in conventional beech timber drying, especially when shorter drying time is reached.
\end{abstract}

Key words: wood drying, energy consumption, conventional drying, oscillation climates, beech timber

SAŽETAK • Cilj istraživanja bio je ustanoviti utjecaj oscilacije parametara zraka tijekom konvencionalnog sušenja piljene bukove građe na potrošnju energije. Izrađen je poseban program koji je omogućivao regulaciju frekvencije (u satima) i amplitude oscilacija (u postocima). Provedeno je ukupno 12 ciklusa sušenja: tri konvencionalnim režimima i devet ciklusa istim režimom, ali s oscilacijom vlage ravnoteže, temperature ili kombinacijom oscilacije obaju parametara. Primijenjene su dvije amplitude (10\% i 20\%) te dvije frekvencije (3i 6 sati) u različitim ciklusima sušenja. U svim postupcima sušenja potrošnja energije bila je razmjerna vremenu sušenja, uz značajan utjecaj vanjske temperature. U ciklusima sušenja s oscilacijom parametara sušenja česta promjena klime, posebno uz kraća vremena promjene (3 sata) i pri većim amplitudama (20\%) imala je značajan utjecaj na potrošnju energije. Usprkos čestim promjenama klime, može se očekivati da je potrošnja energije u režimima s oscilacijom klime jednaka ili čak niža u usporedbi s konvencionalnim režimom sušenja, posebno zbog očekivanoga kraćeg vremena sušenja.

Ključne riječi: sušenje drva, potrošnja energije, konvencionalno sušenje, oscilacija klime, bukova građa

\footnotetext{
${ }^{1}$ Authors are assistant professor, professor and assistant professor at University of Belgrade, Faculty of Forestry, Department of Technology, Management and Design of Furniture and Wood Products, Belgrade, Serbia. ${ }^{2}$ Author is associate professor at University of Ljubljana, Biotechnical faculty, Department of Wood Science and Technology, Ljubljana, Slovenia.

Autori su docent, profesor i docent Sveučilišta u Beogradu, Šumarski fakultet, Odjel za tehnologiju, menadžment i dizajn namještaja i drvnih proizvoda, Beograd, Srbija. ${ }^{2}$ Autor je izvanredni profesor Sveučilišta u Ljubljani, Biotehnički fakultet, Odjel za znanost o drvu i drvnu tehnologiju, Ljubljana, Slovenija.
} 


\section{INTRODUCTION}

\section{UVOD}

Along with the continuous growth of prices of energy sources, the significance of energy consumption in industrial processes has also been growing from decade to decade. Energy consumption is critical for producers who deal with inexpensive products (such as majority of wooden products) as it affects running costs (Kudra, 2004). It is especially important in wood drying, because it is a process that consumes the most energy in the entire chain of timber industry. In the drying process, at least the latent heat of vaporization has to be supplied for removing water from wood. At the same time, conventional kilns, which prevail in the world, consume around $50 \%$ more energy than required to evaporate the water (Elustondo and Oliveira, 2009). Potential improvements in conventional drying are focused on three parameters: drying quality, drying time and energy consumption. One of the possible strategies is the application of artificial variations of certain process parameters (such as temperature, relative air humidity, air velocity, etc.) during the conventional drying. This topic was researched by several authors (De La Cruz -Lefevre et al., 2009; Haygreen, 1965; Langrish et al., 1992; Milić and Kolin, 2008; Poskrobko and Vilchinski, 1983; Sackey et al., 2004; Salin, 2003; Terziev et al., 2002; Welling et al., 2003). Previous researches on oscillating drying have already shown the potential advantages of such a schedule in the sense of shorter drying time and better drying quality of wood (Milić et al., 2013).

In addition to the drying quality and duration of the process, a very important aspect of oscillation changes in conventional drying is also energy consumption. The aim of this paper is to determine if frequent changes of drying conditions, i.e. the constant need for increasing and decreasing of temperature and EMC, increases the energy consumption compared to most used conventional kiln drying.

\section{MATERIAL AND METHODS} 2. MATERIJAL I METODE

The experiment was done in a laboratory kiln with the capacity of around $0.8 \mathrm{~m}^{3}$ of timber (stack 2.1 $\mathrm{m} \times 0.7 \mathrm{~m} \times 0.9 \mathrm{~m}$ ). The kiln consists of two reversible fans, cold water humidification system, electrical heating elements and computer control regulation with eight probes for measuring timber moisture content (MC), and two sensors for measuring temperature and equilibrium moisture content (EMC). The kiln manufacturer assumed that the average values of both temperature and EMC measuring points are always used, which can result in somewhat severe drying conditions, compared to the concept in which only the inlet measuring point is active.

To achieve the EMC and/or temperature oscillations in the previously set amplitudes and frequencies, it was necessary to upgrade the software whose simple activation engages oscillation drying. Additional soft-

\begin{tabular}{|c|c|c|}
\hline Advanced & & 그 $x$ \\
\hline Version & & \\
\hline Oscillations & yes & 7 \\
\hline Phase 1 (h) & 3 & \\
\hline$\Delta$ temp $1(\%)$ & 0 & \\
\hline$\triangle \mathrm{EMC} 1(\%)$ & 10 & \\
\hline Phase 2 (h) & 3 & \\
\hline$\Delta$ temp $2(\%)$ & 0 & \\
\hline$\triangle E M C 2(\%)$ & -10 & \\
\hline
\end{tabular}

Figure 1 Setting the oscillations in a separate window Slika 1. Odabir oscilacija u zasebnom prozoru programa

ware enables setting the duration of both phases (in hours), and the upward and downward deviation values of EMC and temperature (in percent) compared to the existing ones in the conventional schedule (Figure 1). Such amplitudes were chosen in order adapt their sizes to their respective drying phases. Such a definition of deviations was accepted because of technical possibilities of industrial kilns, and because of the influence and importance of oscillation on drying through the entire process (Salin, 2003). The phases are completely separated, which means that they can have different durations and amplitudes of both EMC and temperature. An important requirement for the new software was the easy implementation in industrial kilns, which was a drawback in most previous studies.

The research was done on 38-mm beech timber (Fagus sylvatica L.). The width of the boards was 12$18 \mathrm{~cm}$ and the length $2.1 \mathrm{~m}$. The boards were sawn 2-3 days before each drying cycle from logs of similar diameters $(30-39 \mathrm{~cm})$ cut down on the same tree location in winter time. Twelve drying cycles were carried out in total. Out of these, three were conventional ones that used a moisture content based schedule commonly used in Serbia (Table 1), while nine others used the same schedules, but with oscillations, as shown in Table 2 . The final, XII drying cycle was used for repeating the test run that showed the best results regarding time and quality. In each drying cycle ( $65-70$ boards per run), 30 boards were selected and stacked in the central part of the stack to be used for the assessment of drying quality at the end of the process (Milić et al., 2013). Timber was dried from green state to target $9 \%$ moisture content, measured by the probes in the kiln.

Considering that an electric boiler was used for heating the kiln, the total energy consumption was recorded by an electricity meter. Energy consumptions of all 12 runs were compared. Comparison of energy consumption was done based on the values obtained prior to conditioning phase, because the drying was interrupted at that time. Specific energy consumptions (energy required for the removal of $1 \mathrm{~kg}$ of water from wood) were also calculated and compared because they eliminate the influence of different initial MC between runs. The mass of removed water (difference between stack weight before and after drying) was calculated based on the stack volume and initial and final MC. Energy consumption was followed during the en- 
Table 1 Conventional drying schedule (beech, $38 \mathrm{~mm}$ )

Tablica 1. Konvencionalni režim sušenja (bukva, $38 \mathrm{~mm}$ )

\begin{tabular}{|l|c|c|c|c|c|c|c|c|c|c|c|c|}
\hline MC, \% / Vlažnost drva, \% & 60 & 55 & 50 & 45 & 40 & 35 & 30 & 25 & 20 & 15 & 10 & 5 \\
\hline Temperature, ${ }^{\circ} \mathrm{C} /$ Temperatura, ${ }^{\circ} \mathrm{C}$ & 37 & 38 & 38 & 38 & 38 & 40 & 43 & 47 & 52 & 58 & 62 & 62 \\
\hline EMC. \% / Ravnotežna vlaga, \% & 15 & 15 & 14.6 & 14.0 & 13.6 & 13.1 & 12.1 & 9.2 & 6.8 & 5.4 & 4.4 & 3.9 \\
\hline
\end{tabular}

Table 2 Amplitudes and frequencies of oscillations (12 test runs)

Tablica 2. Amplitude i frekvencije oscilacija u 12 ciklusa sušenja

\begin{tabular}{|c|c|c|c|c|}
\hline \multirow{2}{*}{$\begin{array}{l}\text { Test } \\
\text { run } \\
\text { Ciklus }\end{array}$} & \multirow{2}{*}{$\begin{array}{l}\text { Description } \\
\text { Opis }\end{array}$} & \multicolumn{2}{|c|}{ Amplitude/Amplituda, \% } & \multirow{2}{*}{$\begin{array}{c}\text { Frequency } \\
\text { Frekvencija } \\
\mathrm{h}\end{array}$} \\
\hline & & $\begin{array}{c}\text { EMC } \\
\text { Ravnotežna vlaga }\end{array}$ & \begin{tabular}{|l|} 
Temperature \\
Temperatura \\
\end{tabular} & \\
\hline $\mathrm{I}$ & conventional/konvencionalno & - & - & - \\
\hline II & conventional/konvencionalno & - & - & - \\
\hline III & conventional/konvencionalno & - & - & - \\
\hline IV & oscillations of EMC / oscilacija ravnotežne vlage & \pm 10 & - & 3 \\
\hline V & oscillations of EMC / oscilacija ravnotežne vlage & \pm 10 & - & 6 \\
\hline VI & oscillations of EMC / oscilacija ravnotežne vlage & \pm 20 & - & 3 \\
\hline VII & oscillations of EMC / oscilacija ravnotežne vlage & \pm 20 & - & 6 \\
\hline VIII & oscillations of temp. / oscilacija temperature & - & \pm 10 & 3 \\
\hline IX & oscillations of temp. / oscilacija temperature & - & \pm 10 & 6 \\
\hline $\mathrm{X}^{\mathrm{a}}$ & $\begin{array}{l}\text { oscillations of temp. and EMC / oscilacija ravnotežne vlage } i \\
\text { temperature }\end{array}$ & \pm 10 & \pm 10 & 3 \\
\hline$X I^{a}$ & $\begin{array}{l}\text { oscillations of temp. and EMC / oscilacija ravnotežne vlage } i \\
\text { temperature }\end{array}$ & \pm 10 & \pm 10 & 6 \\
\hline XII & repeated run IV / ponovljeni ciklus IV & \pm 10 & - & 3 \\
\hline
\end{tabular}

${ }^{\mathrm{a}}$ Test runs X and XI: when temperature increases, EMC decreases and vice versa.

${ }^{a}$ Ciklusi X i XI: kada se temperatura povećava, ravnotežna se vlaga smanjuje, i obrnuto.

tire drying cycles, which enabled comparisons to be made between consumption above and below fiber saturation point (FSP), assumed to be at $30 \% \mathrm{MC}$.

\section{RESULTS AND DISCUSSION} 3. REZULTATI I RASPRAVA

Energy consumption (Table 3) ranged from 791 $\mathrm{kWh}$ (run VIII) to $1104 \mathrm{kWh}$ (run I). These values include all energy (heating, fans, valves, servomotors). Very low energy consumption in run VIII was the result of high average outside temperature (temperature, which resulted in smaller losses through heat transmission and air exchange). Energy consumption of the other runs was more or less proportional to drying time, with an always-present influence of the outside temperature (it varied between $-7^{\circ} \mathrm{C}$ and $+15^{\circ} \mathrm{C}$ among runs).
With the exception of run VIII, the lowest energy consumption was recorded in runs IV and XII in which drying time was short. On the contrary, run X had relatively high energy consumption, despite the short duration of drying. The reason is that frequent $(3 \mathrm{~h})$, oppositely directed oscillations of temperature and EMC that have been applied in this run, required frequent vent opening and thus caused higher heat losses. In addition, frequent EMC changes required more frequent humidification, and temperature changes required more heating, both of which increased energy consumption. A similar explanation applies for run XI with the same, but not so frequent (6 h), oscillations. Very high energy consumption was registered in run VI, as a result of $20 \%$ and $3 \mathrm{~h}$ EMC oscillations, which, as for the above mentioned runs, required frequent and long vent opening. In all three conventional runs, relatively

Table 3 Initial and final moisture content (MC), drying time, energy consumption (EC) and specific energy consumption for each test run

Tablica 3. Početni i konačni sadržaj vode u drvu (MC), vrijeme sušenja, potrošnja energije (EC) i specifična potrošnja energije u svim ciklusima sušenja

\begin{tabular}{|c|c|c|c|c|c|c|c|c|c|c|c|c|}
\hline \multirow{2}{*}{$\begin{array}{l}\text { Oscillating parameter(s) } \\
\text { Oscilirajući parametar } \\
\text { Oscillation time / Oscilacija vrijemena } \\
\end{array}$} & \multirow{2}{*}{\multicolumn{3}{|c|}{\begin{tabular}{|c|} 
Conventional \\
Konvencionalno \\
sušenje \\
\end{tabular}}} & \multicolumn{2}{|c|}{$E M C \pm 10 \%$} & \multicolumn{2}{|c|}{$E M C \pm 20 \%$} & \multicolumn{2}{|c|}{$T \pm 10 \%$} & \multicolumn{2}{|c|}{$\begin{array}{c}E M C, \\
T \pm 10 \%\end{array}$} & \multirow{2}{*}{\begin{tabular}{|c|}
$\begin{array}{c}E M C \\
\pm \mathbf{1 0} \%\end{array}$ \\
$3 \mathrm{~h}$ \\
\end{tabular}} \\
\hline & & & & $3 \mathrm{~h}$ & $6 \mathrm{~h}$ & $3 \mathrm{~h}$ & $6 \mathrm{~h}$ & $3 \mathrm{~h}$ & $6 \mathrm{~h}$ & $3 \mathrm{~h}$ & $6 \mathrm{~h}$ & \\
\hline Test run / Ciklus sušenja & I & II & III & IV & $\mathrm{V}$ & VI & VII & VIII & IX & $\mathrm{X}$ & XI & XII \\
\hline Initial MC, \% / Početni sadržaj vode, \% & 89 & 87 & 81 & 85 & 99 & 85 & 80 & 81 & 79 & 91 & 80 & 81 \\
\hline Final MC, \% / Konačni sadržaj vode, \% & 7.4 & 7.5 & 7.7 & 7.8 & 7.4 & 7.8 & 7.9 & 7.6 & 7.8 & 8.8 & 7.7 & 7.9 \\
\hline Drying time, $\mathrm{h} /$ Vrijeme sušenja, $h$ & 335 & 319 & 385 & 279 & 342 & 326 & 341 & 341 & 322 & 297 & 344 & 307 \\
\hline EC, kWh / Potrošnja energije, $\mathrm{kWh}$ & 1104 & 934 & 954 & 917 & 996 & 1021 & 946 & 791 & 918 & 942 & 987 & 862 \\
\hline $\begin{array}{l}\text { Specific EC, } \mathrm{kWh} \cdot \mathrm{kg}^{-1} \\
\text { Specifična potrošnja energije, } \mathrm{kWh} \cdot \mathrm{kg}^{-1}\end{array}$ & 3.00 & 2.60 & 2.89 & 2.63 & 2.40 & 2.93 & 2.91 & 2.39 & 2.86 & 2.51 & 3.03 & 2.61 \\
\hline
\end{tabular}


high energy consumption was recorded (particularly in run I when the average outside temperature was low).

Specific energy consumption was the highest in runs XI and I. Runs VI and VII with high amplitude (20 $\%)$ oscillations had higher specific energy consumption compared to runs with $10 \%$ amplitude, despite the higher outside temperature during drying. The lowest energy consumption was recorded in runs VIII and V. The reason for the low total and specific energy consumption in run VIII was the high outside temperature. An important cause of low specific energy consumption in run $\mathrm{V}$ was a very high initial MC of timber (99 $\%$ ), though the total energy consumption was relatively high. As the energy needed for evaporation of free water is significantly lower than for the bound water, the average specific energy consumption for the whole drying cycle was lower.

Run II, as the shortest conventional cycle, had specific energy consumption at the level of runs IV and XII, while the other two conventional runs had higher energy consumption. Generally, the average specific energy consumption obtained in this research (2.39$3.03 \mathrm{kWh} \cdot \mathrm{kg}^{-1}$ ) is higher than in industrial kilns, which was expected due to high air leakage (leading to heat and humidity losses), higher energy consumption for the fans, heating and humidification - in comparison with the volume of timber. Based on some data, heat losses account for 20-40 \% of total energy in a kiln with the capacity of $11 \mathrm{~m}^{3}$ (Elustondo and Oliveira, 2009) for more than $70 \%$ in kilns of $0.3 \mathrm{~m}^{3}$ or less (Rosen, 1980). In addition, Elustondo and Oliveira (2009) reported that the energy consumption to evaporate cold water used for humidification in small kilns accounts for more than $15 \%$ of the total energy consumption, and if high both dry-bulb and wet-bulb temperatures (over $60{ }^{\circ} \mathrm{C}$ ) are used, it can reach almost 50 $\%$. Generally, in industrial conditions, the percentage of energy needed for heating of air and wood is relatively low (around $5 \%$, according to Denig et al., 2000). When oscillations of drying parameters are used, the humidification system will be switched on more frequently than with conventional schedules, so it is expected that the energy consumption for heating of air and wood in those schedules will also be somewhat higher, but still low compared to the total energy consumption.

There are some differences in comparison of runs regarding total and specific energy consumption. The reason is higher energy consumption due to differential heat of sorption, which had to add drying below FSP. Therefore, drying below FSP had a greater influence on the total energy consumption (60\% of the total energy consumption in run V to $73 \%$ in run VI - Fig. 2). On the other hand, the average specific energy consumption was dominantly influenced by the energy consumption above FSP, due to the higher amount of moisture removal in this range.

Specific energy consumption above FSP (Fig. 3) was between $1.02 \mathrm{kWh} \cdot \mathrm{kg}^{-1}$ in run X and $1.49 \mathrm{kWh} \cdot \mathrm{kg}^{-1}$ in run III. Below FSP, it ranged from $5.20 \mathrm{kWh} \cdot \mathrm{kg}^{-1}$ (run VIII) to $8.07 \mathrm{kWh} \cdot \mathrm{kg}^{-1}$ (run I). Guzenda and Olek (2000) reported values from the literature around 5000 $\mathrm{kJ} \cdot \mathrm{kg}^{-1}\left(1.4 \mathrm{kWh} \cdot \mathrm{kg}^{-1}\right)$ for specific energy consumption above FSP, and more than $10000 \mathrm{~kJ} \cdot \mathrm{kg}^{-1}\left(2.8 \mathrm{kWh} \cdot \mathrm{kg}^{-1}\right)$ below FSP. In this research, specific energy consumption below FSP was much higher because small kilns are less effective at this stage of drying (disadvantages of small kilns are more pronounced at higher temperatures). Above FSP, energy consumption is even lower than usual due to a very high initial MC in all runs. High initial MC means a longer and more efficient capillary flow, higher drying rate and lower specific energy consumption, which affected the average energy consumption above FSP.

The exactness of energy consumption analysis (both for total and specific energy consumption) is limited above and below FSP. There is no strict border between the periods of evaporation of free and bound water. At mean MC levels above FSP, surface MC quickly reaches the hygroscopic range where bound

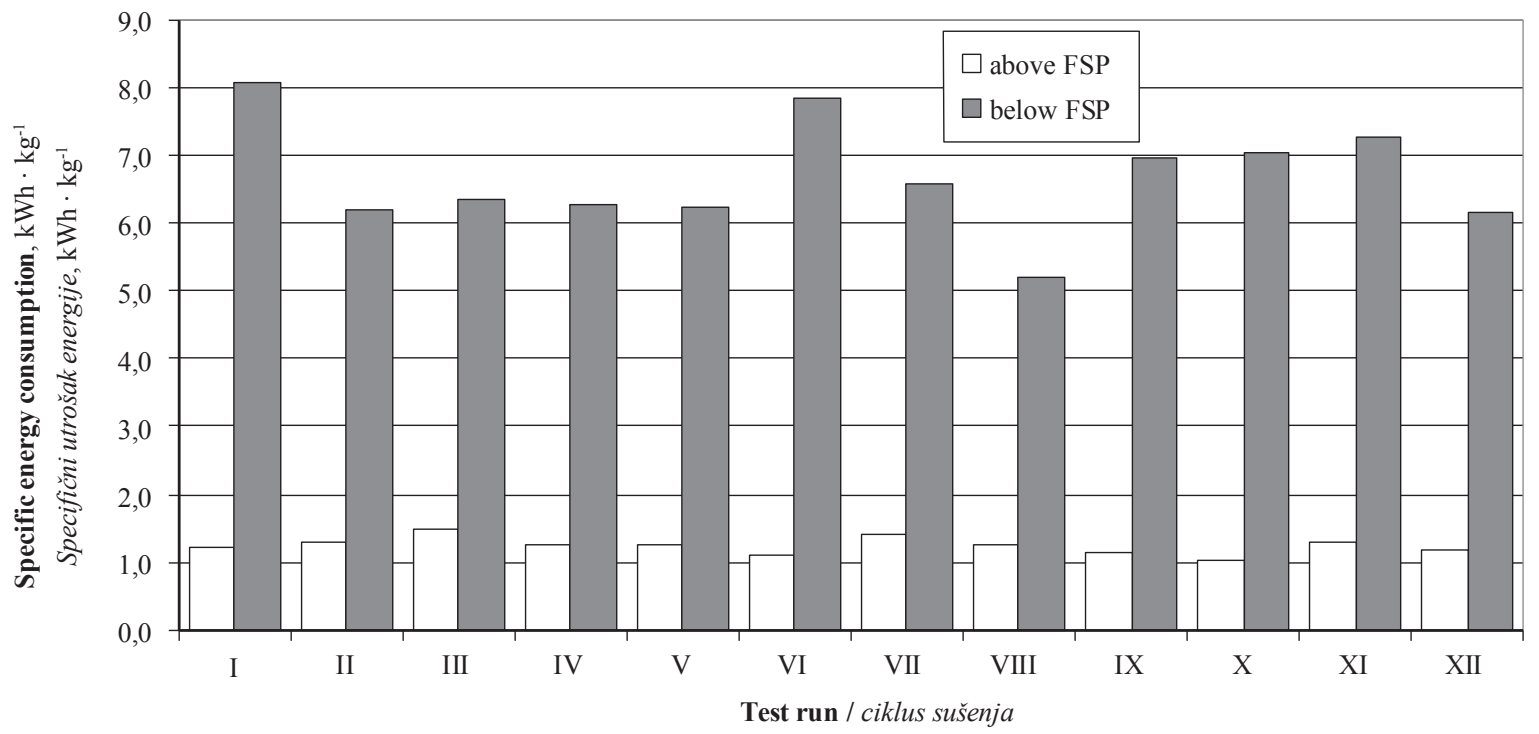

Figure 2 Energy consumption above and below FSP

Slika 2. Potrošnja energije iznad i ispod točke zasićenja vlakanaca 


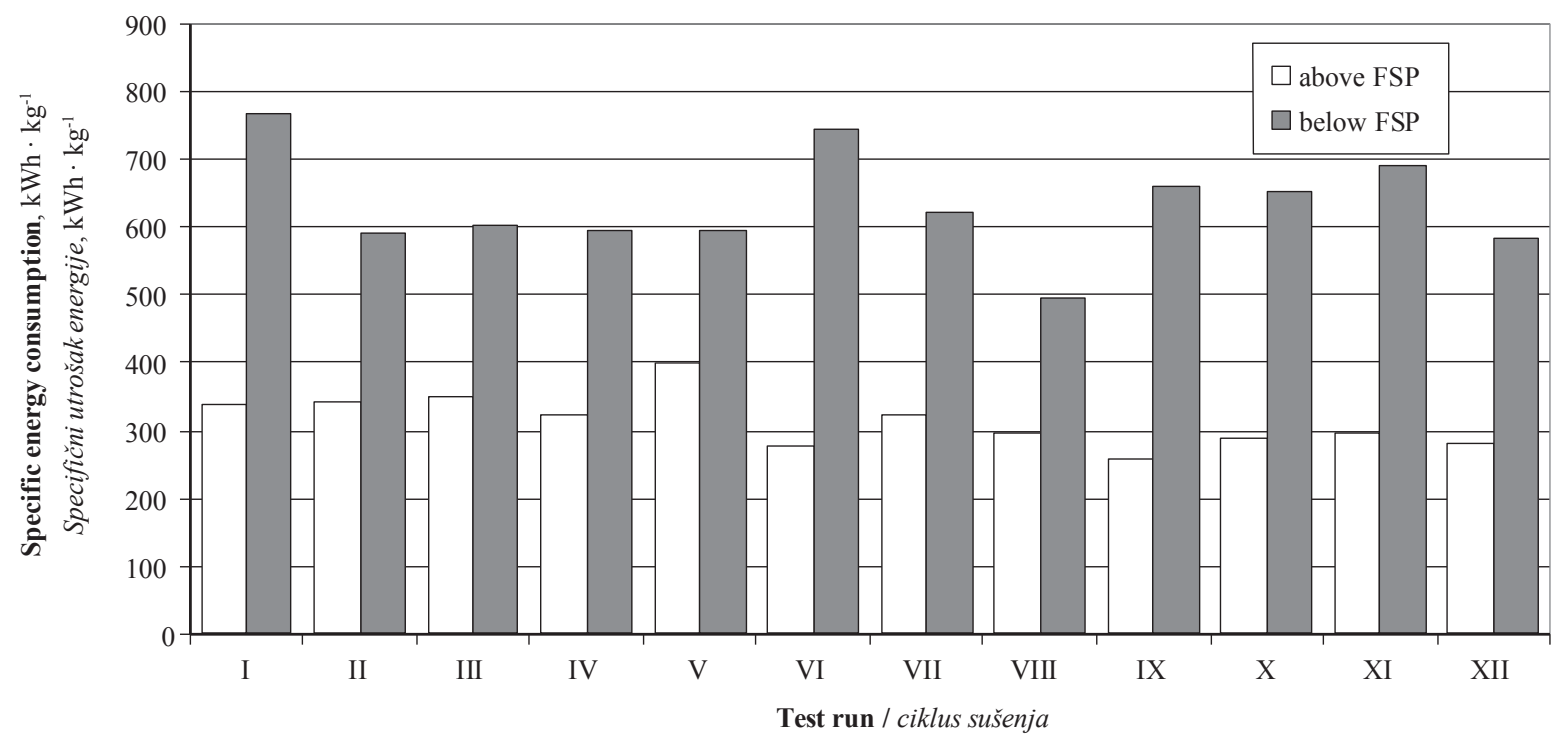

Figure 3 Specific energy consumption above and below FSP

Slika 3. Specifična potrošnja energije iznad i ispod točke zasićenja vlakanaca

water diffusion takes place. Similarly, when individual boards have a mean MC below FSP, liquid migration in inner layers still occurs.

\section{CONCLUSIONS \\ 4. ZAKLJUČAK}

All test runs had energy consumptions proportional to drying time, with an ever present influence of outside temperature. All three conventional runs had relatively high energy consumption. In runs with oscillations, often climate changes influenced to some extent the total energy consumption, especially in runs with short phases (3 hours) and high amplitudes (20 $\%$ ). This indicates that the amplitudes should not be over $20 \%$, otherwise they will increase energy consumption, but also reduce the drying quality. Also, in industrial conditions, the frequency should not be lower than 3 hours. Shorter duration would be insufficient to achieve the set values, the system could be overloaded and finally the energy consumption would be higher. Further work is needed to reveal all aspects of using oscillating climates in industrial conventional drying of beech timber. However, results from this study indicate that energy consumption for oscillation drying, even in industrial conditions, will not be higher than for the conventional runs and, depending on the eventual shortening of drying time, it can be lower. This means that the influence of oscillations of air parameters on the total energy consumption is relatively small, and it once again shows that shortening the duration of the process is the most significant possibility for energy saving in wood drying.

\section{Acknowledgments - Zahvala}

This study was supported by the Ministry of Education, Science and Technological Development of the Republic of Serbia (TR 31041).

\section{REFERENCES}

5. LITERATURA

1. De La Cruz-Lefevre, M.; Aleon, D.; Remond, R.; Perre, P., 2009: Reducing shrinkage defaults and/or drying time thanks to oscillating drying conditions. In: Proceedings of Conference on hardwood processing, Paris, France. p. 6.

2. Denig, J.; Wengert, G.; Simpson, W., 2000: Drying hardwood lumber. Gen. Tech. Rep. FPL-GTR-118. Madison, WI: U.S. Department of Agriculture, Forest Service, Forest Products Laboratory.

3. Elustondo, D. M.; Oliveira, L., 2009: Model to assess energy consumption in industrial lumber kilns. Maderas. Ciencia y tecnología, 11(1): 33-46.

http://dx.doi.org/10.4067/S0718-221X2009000100003

4. Guzenda, R.; Olek, W., 2000: Computer aided analysis of costs and energy consumption of kiln drying of hardwoods. $2^{\text {nd }}$ COST E15 Workshop "Quality drying of hardwood", Sopron, Hungary.

5. Haygreen, J. G., 1965: Status of drying research and practice. Forest Products Journal, 15: 1-7.

6. Kudra, T., 2004: Energy aspects in drying. Drying Technology, 22(5): 917-932.

http://dx.doi.org/10.1081/DRT-120038572

7. Langrish, T. A. G.; Keey, R. B.; Kumar, M., 1992: Improving the quality of timber from red beech ( N. fusca) by intermittent drying. Drying Technology, 10: 947-960 http://dx.doi.org/10.1080/07373939208916489.

8. Milić, G.; Kolin, B., 2008: Oscillation drying of beech timber - Initial experiments. In: Proceedings of COST E53 conference, Delft, The Netherlands. p. 9.

9. Milić, G.; Kolin, B.; Lovrić, A.; Todorović, N.; Popadić, R., 2013: Drying of beech (Fagus sylvatica L.) timber in oscillation climates: drying time and quality. Holzforschung, 67(7): 805-813. http://dx.doi.org/10.1515/hf-2012-0203

10. Poskrobko, A.; Vilchinski, M., 1983: Drying oak by using oscillation schedule. Proceedings of the conference "Wood Drying". Faculty of Forestry, Zwolen (in Polish), pp. 22. 
Milić, Kolin, Todorović, Gorišek: Energy Consumption of Beech Timber Drying... . .

11. Rosen, H. N., 1980: Kiln size sffects energy required to dry lumber. Research note NC-256. St. Paul, MN: U.S. Dept. of Agriculture, Forest Service, North Central Forest Experiment Station.

12. Sackey, E. K.; Avramidis, S.; Oliveira, L. C., 2004: Exploratory evaluation of oscillation drying for thick hemlock timbers. Holzforschung 58: 428-433. http://dx.doi.org/10.1515/HF.2004.065

13. Salin, J. G., 2003: A theoretical analysis of timber drying in oscillating climates. Holzforschung 57: 427-432 http://dx.doi.org/10.1515/HF.2003.063

14. Terziev, N.; Salin, J. L.; Söderström, O.; Rosenkilde, A.; Temnerud, E., 2002: Oscillation drying of Scots pine timber. COST E15 Workshop. Methods for improving drying quality of wood. Santiago de Compostela, Spain, p. 7.
15. Welling, J.; Riehl, T.; Kruse, K.; Rose, B.; 2003: Verbesserte Schnittholztrocknung im Frischluft- /Ablufttrockner durch Wechselklima. Hamburg, Germany, p. 95.

\section{Corresponding address:}

Assistant Professor GORAN MILIĆ, Ph. D.

Department of Technology, Management and Design of Furniture and Wood Products

University of Belgrade - Faculty of Forestry

Kneza Višeslava 1

11030 Belgrade, SERBIA

e-mail: goran.milic@sfb.bg.ac.rs 